London; they redoubled their efforts, and from a prejudiced legislature wrung - as the Barons of Runnymede did from King John-an acknowledgment and an avowel of their merits and their rigints.

No blot could be found upon their new escutcheon; the Graduates seemed to be influenced by the highest feelings of honour; and their amount of talent was indisputable.

The Legislature acknowledged their merits, and granted them their rights, equality with, and all the privileges of Oxford and Cambridge. No sooner was this done than the Senate of the University of London, having first allowed the Graduates' Committee to inform the Graduates that this same Senate assisted them to obtain the desired acknowledgment of their rights, viz., as the legalized physicians of England, seven miles out of London, together with the Graduates of Oxford and Cambridge, - than this same Senate tries to draw a razor across the throat of this infant, already arrived at manhood, the infant man of whom they themselves were the professed guardians. It was an unvarranted outrage, and impolitic. It was an untind onslaught, and undeserved. It was an abutting of the heads of the Senate of the University of London against a rock, (that of the Graduates, ) on which, unless they are "aristocratic as were ever bred," (thick, auctoritate Byron,) they are sure to get fractured.

Queen Victoria and her Parliament gave all and every privilege to the University of London that Oxford and Cambridge enjoyed, in every sense of the word.

Scarcely was that law passed, when the sapient Senate of the University of London resolved valiantly, when they allowed a gentleman to take the M.D. qualification, which the law allowed them to grant, also to take it into their heads to add to his diploma that which the law already allowed him, the M.D. being granted. The object was evident-to snatch from the M.B. of London the laurel which the Queen and Parliament of Great Britain placed on his brow as the reward of industry, highmindedness, and talent; to place him even below the lowest diplomas in the land, some of which a London M.B. would not touch with a fork, and to deny him the rights which the law of the land allowed him.

Alas! suicidal Senate. When you, in your self-sufficiency, thought you were destroying the Graduates, whose welfare you were bound by every tie to support, you were only injuring yourselves. The question in future probably will be, whether a senate doing as you have done, really represent, as a senate should do, the feelings of those over whom they are placed. They will not grant to M.B., in sooth, what they have no power to grant to M.D. or M.B.; but they will do what they can, give a gratuitous insult, and dearly will they pay for it.

Iisten for a moment: it is no day-dream-the non-medical merchants of London have no time for day-dreams. They know the law, however the Senate of the University of London may not know it; and, knowing it, they have not only placed an M.B. of London, Dr. Letheby, as physician, in a most responsible office, to whom the wise Senate by implication would, if they could, refuse the privilege of a physician, but they really have placed second on the list another M.B. of London, Dr. Odling. Alas, poor Senate! But even worse comes: the third on the list of candidates was an M.D. of London University also, Dr. E. Smith. How many of the Senate joined him in his canvass? None, probably; but he was well backed by the non-medical Corporation.

Now, as you are fond of statistics, behold!-tell it to the Senate-see what the Corporation of London thinks of the Senate"s implied "veto" on the M.B. to practise; and see also what they think of the sterling worth of the Craduates of that University even against " all England":-

FIFTEEN candidates applied for the position of Officer of Health. One hundred and fifty votes were given. For whom? Four candidates absolutely got ninety-one out of that number of one hundred and fifty; and the REMAINING ELEVEN got sixtynine.

Who were these candidates - these four who gained the ninety-one votes, or, on an average, upwards of twenty each; while the remaining candidates averaged not six and a half each? They were Graduates of the University of London. And who were these two M.B.'s to whom fifty-seven votes, or an average of twenty-eight and a half, were given? They were Graduates of London to whom their sapient Senate have not yet decided on granting what they have no power to grart or withhold-the right to practise as physicians. Alas, poor Senate! We have no generals abroad, and our men are sacrificed; we have no heads at home, and our interests are neg. lected. Does red-tapeism rule everywhere? or cannot the right men be put in the right places anywhere? How many 422
Graduates of London are on the Senate of their own University? or, will you kindly tell us the names that compose the Senate? Pray print them that we may reverse them. Are they preAdamites, megatheria, or men of the present world? Would they value gratuitons advice? If so, let them grant to M.D. and M.B. respectively their diplomas, and simply and gracefully at the same time testify that each is legally empowered to practise " according to the Act of \&c., \&c." They have at present placed themselves in the most unenviable position they were ever in, either as gentlemen or men of business.

Oetober, 1855.

I am, Sir, yours \&c.

a Graddate.

\section{MEDICAL PRACTITIONERS OF CHICHESTER AND LIFE ASSURANCE.}

To the Editor of THE LANCET.

SrR,-Having admitted into your columns last week an imperfect copy of a resolution entered into by the medical practitioners of Chichester, signed " B. L.," in February 2nd, 1852 , in which is specified " that the medical practitioners of Chichester hereby determine and agree that they will not in future fill up and sign medical certificates relative to life assurance gratuitously, or for any fee less than a guinea." From the tenour of this resolution, another medical man and myself have thought it right to withdraw our observance of the same; before doing this, however, endeavours have been made by us, first, at a meeting, to have the resolution in some mea. sure modified, and also by speaking to some individuals, but with only avowals of their determination that no alteration could or should be effected. We had no alternative but to adopt the notice, which we sent to the members who signed the resolution, feeling deeply how injuriously it acted on small insurers, precluding them from obtaining the benefit, if such there be, from insurances. But to prove how little the prin. ciple of the resolution was valued, another resolution was passed, worded thus: "That it is the opinion of the meeting, that the resolution in relation to the fees payable by insurance offices, agreed to by the medical practitioners of Chichester, on February the 2nd, 1852, was not intended to interfere with the examination of any person or persons at any distance beyond ten miles from Chichester, such persons themselves residing at such a distance from Chichester." This evidently met the convenience of some.

We have now stated facts. Will you favour us by the in sertion of this in your next?

We do not positively know the writer of the article, no medical practitioner bearing the initials of " B. L." living at Chichester. We will not, however, follow his example, but sign ourselves,

October, 1855.

WILITAM C. CAFFIN, EDWARD LEECH.

\section{THE PROVINCIAL MEDICAL AND SURGICAL ASSOCIATION. \\ To the Editor of THE LANCET.}

SrR,-Amongst all the benefits which your correspondent, "J. P." in THE LANCET of September 29th, enumerates as capable of attainment by members of the Provincial Medical and Surgical Association, if the sums paid into its treasury were properly employed, there is none which strikes me as being of such paramount advantage as the establishment of a fund for the protection of our members against persecution, whether by unjust legal proceedings, or otherwise. Books we have, most of us, and more than we have time to read. Medical scholarships could only be enjoyed by a few in our profession, and those few of a future generation of medica practitioners-not the present members of the Association. The payment of the cost for attending the annual gatherings of the Association is grudged by no member; he expects to derive pleasure from a short tour, as well as from the meeting, and moreover, the expense incurred by him is voluntary, and unconnected with his yearly subscription. Contributions to the Medical Benevolent College, or other charitable medical foundations, wound be, indeed, worthily bestowed from our funds, and would far outweigh in utility the maintenance of a journal. But what we really most urgently require is, for the Council of the Association to take up the cause of medical practitioners whose characters and conduct may be unjustly vilified, and whose interests suffer in proportion, from wąaton 